\title{
Marginal Effect of Direct Tax on Profits: A Study on the Taxation of the Finance Industry in Brazil
}

\author{
José Antonio de França ${ }^{1}$, Osvaldo Cândido da Silva Filho ${ }^{2} \&$ Wilfredo Sosa Sandoval ${ }^{3}$ \\ ${ }^{1} \mathrm{PhD}$ in Accountancy, University of Brasilia (UnB), Brazil \\ ${ }^{2} \mathrm{PhD}$ in Economics, Catholic University of Brasilia (UCB), Brazil \\ ${ }^{3} \mathrm{PhD}$ in Mathematics, Catholic University of Brasilia (UCB), Brazil \\ Correspondence: José Antonio de França, $\mathrm{PhD}$ in Accountancy, University of Brasilia (UnB), Brazil. E-mail: \\ franca@itecon.com.br
}

Received: December 13, 2018

Accepted: January 9, 2019

Online Published: January 30, 2019

doi:10.5539/ijef.v11n3p1

URL: https://doi.org/10.5539/ijef.v11n3p1

\begin{abstract}
This article addresses the direct taxation on banks' profits in Brazil and tests the influence of net fiscal adjustment (NFA) on direct tax on profit (DTP) by introducing the marginal effect of direct taxation (MgET). Measuring DTP is a complex process that involves adjustments in fiscal accounting procedures to recognize economic transactions by using specific standards. Besides fulfilling the objectives of identifying recognized direct tax (RT) and calculating NFA, MgET is identified by the algebraic sign of NFA, which is the sufficient, necessary and only condition to evaluate the existence of cash synergy/entropy in firms, with the reduction/increase of DTP. By using a sample containing data from the 40 biggest banks in Brazil, from 2010 to 2017 , under the positivist methodology, the research results are strongly robust in indicating that NFA has a significant impact on DTP and on $M g E T$, producing cash synergy.
\end{abstract}

Keywords: cash synergy and entropy, Direct tax on profit (DTP), Marginal effect of direct tax on profit (MgET), Net fiscal adjustment (NFA)

\section{Introduction}

Researchers around the world have focused on income, output and consumption taxation. Mendoza, Razin, and Tesar (1994) and Devereux and Griffith (2002) studied direct and indirect taxation in industrialized countries and income and other taxes on firms based on the geographical location of industrial production in general.

This article addresses the direct taxation on profits of Brazilian banks and presents the marginal effect of direct tax on profit (MgET). Measuring direct tax on profit (DTP) is a complex process that involves adjusting procedures concerning guidelines from accounting standards and determinations from legal norms on taxation. MgET is obtained by the difference between DTP nominal and effective rates.

The International Accounting Standard IAS 12, (IASB, 1996), is conceptual-theoretical based and implements standards to recognize and measure economic transactions of firms. For taxation purposes, there is a legal norm that prescribes adjustments to the procedures determined by accounting standards. In this context, DTP is calculated in accordance to Taxable Profit (TP), for firms of any size or activity, and in Brazil is composed by the federal corporate income tax (IRPJ, Portuguese acronym) and by the social contribution on net profits (CSLL, Portuguese acronym), as determined by Federal Decree no. 3,000/99 and Federal Law no. 7,689/88.

However, for firms with high annual revenue and firms from specific business activities, TP is the same as the actual profit (AP). Therefore, AP, which presents complex measurement, is the method used for direct corporate taxation for large firms as well as for those from specific business activities, differentiating these from small firms, for which $T P$ is applicable.

In Brazil, the legal tax norm determines that firms that are taxed by the AP method recalculate accounting profits, by algebraically adding a net fiscal adjustment (NFA), in order to obtain the calculation basis for DTP. NFA is obtained by adding net permanent differences (NPD) to net temporary differences (NTD) that influence cash synergy/entropy and impact due tax amounts. $N P D$ are obtained by calculating the difference between total non-deductible expenses and total non-taxable revenue. NTD correspond to the difference between total expense 
and total deferred tax revenue. $A P$, calculated in this manner, is the $D T P$ calculation basis, which, according to Edgeworth (1897), must take into consideration not only the laws of incidence, but also the principle of equal sacrifice.

The DTP calculation process, under the $A P$ method, is different from other $T P$ processes because it produces compulsory and crediting tax effects, as discussed by Boadway, Bruce, Mckenzie \& Mintz (1987) and Graham (1996). The crediting tax effect only happens when $A P$ is negative $(A P<0)$, generating $D T P$ inventory that is only recognized in a firm's balance sheet when the theoretical requirement for an asset's recognition is met. The required payment value of DTP and the crediting tax effect, calculated according to $A P$, are influenced by the algebraic sign of $N F A$, which may not convey the sense of neutrality and pure profit as discussed by Edgeworth (1897) and RUF (2012). Such non-neutrality is a consequence of the permanent adjustment which excludes from the $A P$ process tax credit of non-deductible expenses and the tax debit of non-taxable revenue.

However, in order to achieve tax neutrality, there must not be discretionary practices that produce biased profits. If such practices occur, then there is what the literature names result-based management, as addressed by Formigoni, Antunes, and Paulo (2007) and Rezende and Nakao (2012), as it distorts the pure profit value. Beyond this, for achieving neutrality, there must not also occur any other stimulus that generates DTP reduction, such as incentives or any other form of tax waiver.

The choice of the banking business for this research is relevant as this is a sector regulated by the Central Bank of Brazil (BCB) and by the Securities and Exchange Commission of Brazil (CVM), which impose rigorous governance criteria and enforcement of specific legal and accounting norms. This double regulation makes it possible to gather representative examples of elision accounting practices and of properly elaborated financial statements showing DTP.

The main interest and motivation of this research is to assess the influence of NFA on DTP. Thus, the problem to be investigated is the measurement of the impact of NFA upon DTP and the respective effect on cash economy/diseconomy of Brazilian banks. To answer the research questions, the proposed means are (a) identifying the recognized direct tax (RT) in standardized financial statements; $(b)$ calculating estimated direct tax (ET); $(c)$ calculating NFA and identifying its impact upon DTP; and $(d)$ calculating the marginal effect of direct tax on profit (MgET) and its consequences upon the cash economy/diseconomy with cash synergy/entropy.

The marginal tax rate on profit was studied by Boadway, Bruce, Mckenzie, Mintz (1987), in mining firms in Canada, and by Graham (1996), in corporate debts resulting from incentives for interest deduction. This article expands the mentioned studies by focusing on cash economy/diseconomy due to guideline differences between accounting standards and legal tax norms.

The results obtained by the research are relevant to the literature of the field because they show the materialization of legal norm determinations in the adjustment of profit as calculated by following accounting standards/practices, increasing/reducing the direct tax burden on profits, with impact on firms' cash flow and structure of working capital, as well as on shareholder remuneration. These results, however, are limited in the fact that they are applicable only to the finance industry in Brazil, more specifically to the banking business; they might be different if applied to other business activities in the domestic economy or in other countries.

In addition to this introductory section, the article is structured as follows: Theoretical discussion (2), which presents and discusses research related to the subject; Methodological preliminaries (3), which present and describe the variables and theoretical basis of the research development; Methodology (4), which demonstrates the equations of the model used to obtain the results and the research method; Description of data and analysis of results (5), which analyzes the data and discusses the results gathered with the application of the model; Conclusions (6), which summarizes the main findings of the research and its respective contributions to literature; and References, where the sources used are listed.

\section{Theoretical Discussion}

This section discusses the main contributions from the literature related to this subject, which form the basis for this research's advancements. The contributions are listed in two topics: legal milestone and related research.

\subsection{Legal Milestone}

In Brazil, direct taxation on profit is governed by Federal Decree-Law no. 3,000/99 and by Federal Law no. $7,689 / 88$, which regulate, respectively, the determination of the calculation basis for tax on income and proceeds of any nature (IRPJ, Portuguese acronym) and on the social contribution on net profits (CSLL, Portuguese acronym), as well as tax calculation rules. 
Besides the legal norm that regulates the incidence of direct tax on profit, the international accounting standard IAS 12 (IASB, 1996) regulates the recognition procedures for this tax, for financial result purposes as well as for assets purposes. Such recognition procedures may influence firms' financial position, either higher or lower, due to the algebraic sign of $N F A$, affecting profitability, rentability and liquidity indicators.

As the research is centered on the Brazilian finance industry, the recognition of direct tax follows the guidelines of Resolution no. 3,059/02, published by the Brazilian National Monetary Council (CMN, Portuguese acronym), especially regarding the inventory of tax credit when the calculation basis of the DTP is negative, using the method of actual profit $(A P)$. According to these guidelines, if the criteria to recognize tax credits are not met, a bank's financial statements must not show the referred credit and its value will not be observed by external users of the information.

\subsection{Related Research}

The milestone of the taxation theory is set by EDGEWORTH (1897), who declared that the taxation science encompasses two subjects to which the pure theory character may be attributed:

"the laws of incidence, and the principle of equal sacrifice."

In this theory, several aspects of direct and indirect taxation are discussed, such as tax upon output, consumption, property and profits. Regarding taxation on profits, he stated that

"A tax on profits -...- cannot be levied without some little disturbance of economic margins and this proposition might be illustrated by considering the classical theorem that the remission of rent to all farmers would not lower the price of corn."

RUF (2012) stated that a tax on firms' profits is neutral if the current net value of profit after-taxes has the same sign as the current net value before taxes and, consequently, a neutral tax does not affect investment decisions. He argues also that, given the complexity of the concepts of general balance, neutral taxation is a good starting point to evaluate tax systems.

Boadway, Bruce, Mckenzie, and Mintz (1987) evaluated the marginal tax rate of mining firms in Canada, including tax on profits. They developed two equations, which are (a) the marginal taxation model given as $\left[t=\left(r_{g}-r_{n) /} / r_{g}\right]\right.$, where $\mathrm{r}_{\mathrm{g}}$ is the gross of tax return to capital, and $\mathrm{r}_{\mathrm{n}}$ is the net of tax return to capital; and (b) the taxation model for development and exploration activities given as $\left[t_{r}=\left(r_{g}-w\right) / w\right]$, where $w$ is normalized to unity. Their main conclusions suggest that, to the extent that firms cannot use all tax deductions, the effective tax rates calculated would be underestimates when the tax rate is negative, and overestimates when the tax rate is positive.

Graham (1996) addressed the marginal effect of profit taxation in corporate debt issues due to interest deduction incentives. The calculations of marginal tax rates, consistent with the tax code, indicate that there are substantial variations throughout time and, among firms, variations when subgrouping data of large and small firms.

Devereux and Griffith (2002) studied income and other taxes on firms based on the geographical location of production. The research focused on tax policy issues and the impact of taxation on cross-border capital flows in an open economy, with respect to the size of available capital and its aggregate distribution by type of property. The research results are not conclusive, but there are some evidences that taxes affect a firm's location and investment decisions, but this effect was nor quantified.

Mendoza, Razin, and Tesar (1994) proposed a method to calculate tax rates using national accounts and internal revenue statistics. They built time series using the rates for industrialized countries and their findings convey that tax on labor, capital and consumption fluctuated heavily in response to changes in taxes and policies relative to credits, exemptions and deductions. Tax on capital and on consumption did not present any relevant trend, while tax on income rose over time in all G-7 countries. Indirect and income tax rates tend to be higher in European countries when compared to Japan and the United States, while effective tax rates on capital gains in the US are higher than in other industrialized countries, except for the United Kingdom and Japan.

Formigoni, Antunes, and Paulo (2007) analyzed the differences between accounting and taxable financial results of publicly traded Brazilian companies between 2000 and 2005. The aim of this analysis was to verify the relationship between the management of accounting results and of taxable results and the difference between both. They used a sample of 276 firms, but state that they could not find evidences showing that the difference between both results occurred due to tax and accounting management. 
Rezende and Nakao (2012) also researched result-based management and investigated whether the amount of taxable profit was used as a measure of economic incentive in publicly traded Brazilian companies between 1999 and 2007. Their conclusions suggest that there is a negative relationship between taxable profit and result-based management, which can be influenced by economic interests related to taxation.

As Iudícibus and Pohlmann (2010) show, tax law adjustments related to non-deductible expenses, non-taxable revenue and accumulated losses cause situations in which the amounts recognized as IRPJ (federal corporate income tax) and CSLL (social contribution on net profits) differ from the expected average tax rate on profit, which happens because of the magnitude of these items when calculating tax on profit. For these authors, the way to determine direct tax on profit is biased towards generating discrepancies between tax amounts recognized in the results and due tax amounts.

Eberhartinger (1999) studied the relationship between corporate accounting and tax accounting, and concluded that the rules guiding both accounting segments do not interfere in one another. Therefore, in theory, the information produced by corporate accounting is free from tax accounting influences, but the tax calculation basis quantified by tax accounting depends on the information provided by corporate accounting. The author's conclusions seem to be conflicting since, should one situation depends on the other, it would not be reasonable to conclude that they are independent from one another.

Schrand and Wong (2003) studied the provisions found in SFAS 109, which is discretionarily used by firms to affect the temporary fiscal adjustment in the finance industry in the USA. With such discretionary power, firms can use "hidden reserves" to manage profits. Their findings indicate that several banks do not recognize provisions to manage profits, but follow the SFAS 109 guideline. However, if banks are sufficiently capitalized to absorb the impact of fiscal adjustments on capital, the total provision amounts increase banks' capital.

Holland and Jackson (2004) analyzed the provisions of deferred taxes during a period of time in which the reward for managers could have been very high, especially in relation to partial disclosures of higher or lower tax provisions. In their analyses, they used a sample of 58 firms in the fiscal years between 1991 and 1992, which represented $20 \%$ of the maximum potential of deferred tax liabilities and $9 \%$ of profits before taxes. Their findings indicate that firms used a great amount of exceeding expenses beyond legal expenses, with the aim of managing results, instead of focusing on a specific item. Complementing the authors' findings, it must be emphasized that exceeding expenses are part of permanent and temporary differences, which are studied in this research.

\section{Methodological Preliminaries}

This section presents the variables that compose the model equations as well as the theoretical framework that support the development of this research to obtain the expected results.

\subsection{Variables of Interest}

The variables presented in Table 1 below are part of the model equations that meet the objectives and answer the research question. The sign of the variable of interest NFA will suggest cash economy or diseconomy, synergy with a (-) sign and entropy with a (+) sign, respectively.

Table 1. Variables in the model equations

\begin{tabular}{ll}
\hline Variable & Variable description \\
\hline PBCT & Profit before corporate income tax (IRPJ) and before social contribution on net profits (CSLL). It representes firms' \\
& economic performance before DTP. \\
RT & Recognized direct tax. It depends on NFA and may be positive or negative. \\
NFA & Net fiscal adjustment. It can take on a positive or negative sign. It follows the determinations of the legal tax norm, and is the \\
& sum of NPD and NTD. \\
ET & Estimated direct tax. It does not depend on NFA, may be positive or negative and depends only on PBCT. \\
TP & Taxable profit. The terminology is used for any taxation method and includes the AP method. \\
AP & Actual profit. It is a type of TP used in large firms or firms with specific business activities. It may be positive or negative \\
& and depends on PBCT and/or NFA. \\
MgET & Narginal effect of direct taxation on profit. It maximizes cash flow utility when RT < ET. \\
$\delta$ & Effective tax rate of DTP. It depends on NFA. \\
$\delta^{*}$ & Net temporary difference. It is the algebraic sum of TA and TE and may be positive or negative. \\
NTD & Temporary additions. Expenses with deferred tax credit. \\
TA & Temporary exclusions. The amount of revenue with deferred tax debit. \\
TE &
\end{tabular}




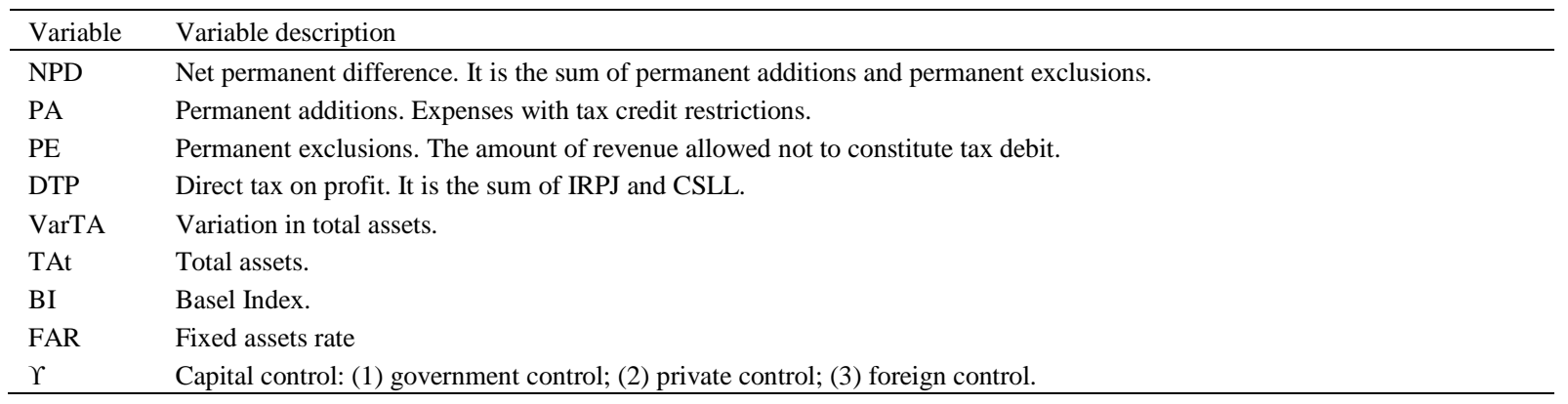

Fonte: the authors.

\subsection{Theoretical Framework}

The theoretical framework supporting the development and the results of this research is grounded on the premise that, for any NFA lower than zero $(\forall$ NFA $<0)$, the marginal effect is a reduction of DTP. Otherwise, the marginal effect is an increase in tax.

\section{Methodology}

The methodology used in this research is positivist, grounded on specific equations and theoretical models, complemented by statistical and econometric analyses. Specific equations are used to calculate the data for the variables of interest of the theoretical model, to meet the objectives and to contribute for the solution of the research investigation.

\subsection{Net Temporary Difference (NTD)}

$N T D$ is obtained by the algebraic sum of temporary additions (deferred expenses) and temporary exclusions (deferred revenue), as recommended by the tax legislation. Such deferral is due to the legal norm's requirements to postpone payable tax recognition until there is cash inflow/outflow.

$$
N T D_{j, t}=T A_{j, t}-T E_{j, t}
$$

\subsection{Net Permanent Difference (NPD)}

$N P D$ is obtained by the algebraic sum of expenses with restrictions (permanent additions) and revenue with non-taxable permissions (permanent exclusions), which represent permanent exclusions from the calculation basis of direct tax, also identified as non-deductible expenses and non-taxable revenue.

$$
N P D_{j, t}=\left(P A_{j, t}-P E_{j, t}\right)
$$

\subsection{Theoretical Net Fiscal Adjustment (NFA)}

The theoretical NFA is built from NPD and NTD.

$$
N F A_{j, t}=N P D_{j, t}+N T D_{j, t}
$$

While NFA is theoretically defined as such, because NPD and NTD are not present, however, NFA cannot be calculated. One of the ways to calculate it is using the theoretical model of $R T$.

\subsection{Recognized Tax $(R T)$}

RT is directly obtained from the financial statements of each firm and cannot be calculated without the identification of NFA. Because of this limitation, creating a theoretical pricing model is necessary.

$$
R T_{j, t}=\left(P B C T_{j, t}+\mathrm{NFA}_{\mathrm{j}, \mathrm{t}}\right) * \delta ; \quad \delta \in R^{+}
$$

From this theoretical RT model, NFA is identified as one of the forms to calculate it.

\subsection{Empirical Net Fiscal Adjustment $\widehat{N F A}$}

$\widehat{N F A}$ is empirically obtained by the manipulation of equation (4) that defines the $R T$.

$$
\widehat{N F A}_{j t}=\frac{T R_{j t}}{\delta}-P B C T_{j, t}
$$

4.6 Effective Tax Rate of Direct Tax on Profit ( $\left.\delta^{*}\right)$

$\delta^{*}$ corresponds to the relationship between $R T$ and $P B C T$. This relationship defines a firm's direct tax burden. Both $R T$ and $P B C T$ are observed directly from financial statements. The $\delta^{*}$ calculated in this way is the reference which the marginal effect of direct tax $(M g E T)$ depends on.

$$
\delta^{*}=R T_{j t} \cdot \frac{1}{P B C T_{j t}}=\delta+\frac{\delta . N F A_{j t}}{P B C T_{j t}}
$$




\subsection{Marginal Effect of Direct Taxation on Profit (MgET)}

$M g E T$ signals the marginal effect of the direct tax on a firm's cash flow, via synergy or entropy in cash generation. The direction of the marginal effect is indicated by the NFA sign.

$$
\operatorname{MgET}_{j t}=\delta_{j t}^{*}-\delta_{j t}
$$

Theorem

If $\mathrm{PBCT}$ is positive, then:

Proof

$$
\operatorname{sign}(\operatorname{MgET})=\left\{\begin{array}{l}
(-)=>\text { cash economy }(\text { synergy }) \\
(+)=>\text { cash diseconomy }(\text { entropy })
\end{array}\right.
$$

As $\delta^{*}=\left(\delta+\delta N F A * P B C T^{-1}\right)$ is known, therefore $M g E T=\left[\left(\delta+\delta N F A * P B C T^{-1}\right)-\delta\right]$. This shows that the MgET sign is the same as the NFA sign, because PBCT is positive.

Cash synergy is the economy of not disbursed tax, which happens by the difference between the effective tax rate and the nominal tax rate of DTP, which is signaled by an NFA with a negative sign (-).

Cash entropy is the diseconomy of the tax caused by the difference between the effective tax rate and the nominal tax rate of DTP, which is identified by an NFA with a positive sign (+).

Such NFA sign statement is only true for PBCT > 0. In the opposite situation, the NFA sign will be inverted.

\subsection{Variation in Total Assets (VarTA)}

VarTA measures the increase or the reduction of a firm's total assets in over time.

$$
\operatorname{VarT} A_{i t}=\frac{\left(T A_{j t_{i}}-T A_{j t_{f}}\right)}{T A_{j t_{i}}}
$$

Where $T A_{j t_{i}}$ represents the total assets of firm $j$ in the initial period and the $T A_{j t_{f}}$ represents the total assets of firm $j$ in the current period.

\subsection{Hypothesis Test}

The model tests MgET's dependence to NFA, and to the variation in total assets. These variables are chosen because NFA impacts RT, and VarTA theoretically impacts revenue and, consequently, DTP.

$$
M g E T_{j t}=\alpha+\beta_{1} N F A_{j(t-1)}+\beta_{2} \operatorname{VarTA}_{j_{(t-1)}}+\varepsilon_{j t}
$$

Where $\alpha$ is the constant term; $\beta$ is the coefficient that explains the impact of the variables of interest on the marginal effect of direct taxation on profit; and $\varepsilon$ is a random error.

\subsection{Direct Tax On Profit (DTP)}

DTP is obtained by the application of the nominal tax rate $(\delta)$ upon AP and represents the sum of IRPJ (federal corporate income tax) and CSLL (social contribution on net profits).

\section{Description of Data and Analysis of Results}

$$
D T P_{i t}=I R P J_{i t}+C S L L_{i t}
$$

This section presents the sample data and the analysis of the results. The observations and the list of financial institutions can be found in Appendix A, Tables A1 and A2.

\subsection{Data Description}

The primary data were gathered from the standardized financial statements of the 40 largest banks in the Brazilian finance industry, classified in accordance to total assets criteria, between 2010:1 and 2017:3. The standardized financial statements were obtained from the Central Bank of Brazil's repository "50 largest banks and the consolidated National Financial System" and from "ifdata", in the base date of September 2017, with quarterly frequency. The primary data used are: PBCT, RT, TAt, and $\Upsilon$, whose description can be found in Chart 1 of Section 3, which are obtained directly from the standardized financial statements and from the tax legislation.

The distribution observations that constitute the variables of the research were calculated according to the analytical method described in Section 4 and the results show that the proposed objectives were met and the research question was answered.

Throughout the quarters prior to the third quarter of 2017, several banks alternated their ranking positions, but the classification takes into consideration the ranking position of September 2017.

\subsection{Analysis of the Sample Observations}

The total assets in the sample are shown in Table 2, segregated by type of capital control. The observations of 
the column "Total Assets - all institutions" show that more than $41 \%$ of the Brazilian finance industry are under government control, with the two largest institutions, B7 and B17 (Table A1, Appendix A), concentrating more than $70 \%$ of the assets of all institutions controlled by the State. The largest participation in the finance industry is from private-controlled institutions, with more than $43 \%$ of total assets and the smallest participation is from institutions with foreign control, with less than $16 \%$.

Table 2. Stratification of total assets of the Brazilian finance industry - sample of the 40 largest banks under the criteria of total assets - from 2010:1 to 2017:3

\begin{tabular}{ccccc}
\hline$\Upsilon$ & Total assets all institutions & Banks in the sample & Total assets banks in the sample & Sample assets in the institutions' total assets \\
\hline 1 & 0,4171 & 9 & 0,4891 & 0,9791 \\
2 & 0,4304 & 13 & 0,3644 & 0,7071 \\
3 & 0,1525 & 18 & 0,1465 & 0,8020 \\
Total & 1,0000 & 40 & 1,0000 & 0,8350 \\
\hline
\end{tabular}

Source: ifdata. Elaborated by the authors.

Table 2 above shows that government controlled banks represent $22.5 \%$ of the sample $(9 / 40 * 100)$ and their assets comprise $48.91 \%$ of the total assets of the 40 largest banks in Brazil. This percentage is significantly larger than private and foreign controlled institutions, which concentrate $36.44 \%$ and $14.65 \%$, respectively, as shown in the column "Total assets - banks in the sample".

The last column to the right of Table 2 above, "Sample assets in the institutions' total asset", shows the participation of the sample banks' assets in the total assets of all financial institutions, which is $83.5 \%$. This participation reveals clear concentration of the finance industry in Brazil on the 40 largest banks, within a population of more than 1,500 institutions. The segregation of this participation indicates an elevated capacity of this sample to explain the Brazilian finance industry since the smallest group, that of private controlled banks, is more than $70 \%$.

\subsection{Analysis of the Marginal Effect of Direct Taxation on Profit (MgET)}

Table 3 below shows the marginal effect of direct tax on profit, stratified by banks' capital control, identified via Equation (7). Part (a) shows the effects of the NFA sign towards MgET, quantifying the quarterly observations affected by cash economy/diseconomy, respectively in columns "SynergyFC" and "EntropyFC", confirming the Theorem of the previous section. Part (b) shows how MgET is distributed by capital control, in number of quarters in columns "SynergyFC" and "EntropyFC".

Table 3. Quarterly distribution of MgET, by capital control of the sample with the 40 largest banks in the Brazilian finance industry - from 2010:1 to 2017:3

\begin{tabular}{cccccc}
\hline & No. & (a) & \multicolumn{2}{c}{$\begin{array}{c}\text { Distribution of MgET by capital control in the } \\
\text { total observations }\end{array}$} & \multicolumn{2}{c}{$\begin{array}{c}\text { (b) Distribution of MgET by capital control } \\
\text { quarterly observations }\end{array}$} \\
\cline { 3 - 7 } & Banks & SynergyFC & EntropyFC & Total & SynergyFC \\
\hline 1 & 9 & 252 & 27 & 279 & 28,00 \\
2 & 13 & 334 & 69 & 403 & 25,69 \\
2 & 18 & 439 & 119 & 558 & 24,39 \\
Sum & 40 & 1025 & 215 & 1240 & 25,625 \\
\hline
\end{tabular}

Source: the authors.

The results of parts (a) and (b) of Table 3 reveal a significant efficiency of banks in producing cash economy, as indicated by the data in columns "SynergyFC". The greatest performance in the generation of cash synergy, in number of observations, comes from the banks with foreign control shown in part (a). In number of quarters, the greatest performance comes from banks with governmental control shown in part (b). However, it is relevant to point out that there is an inversion in the ranking of banks with governmental control and foreign control. Government controlled banks come first in number of quarters and last in number of observations. Foreign controlled banks come last in number of quarters and first in number of observations. Banks with private control maintain their intermediate positions in both parts (a) and (b).

These results reveal that the Brazilian finance industry found a management framework that allows them to economize cash with the reduction of direct tax on profit. The results are consistent with the findings of Graham (1996) and Boadway, Bruce, Mckenzie, Mintz (1987), where effective tax rates lower than nominal tax rates 
prevail throughout the whole sample period, with robust evidences that, in Brazil, the finance industry manages revenue reducing direct tax on profits, opposing Formigoni, Antunes, and Paulo (2007)'s findings.

\subsection{Descriptive Statistics Analysis}

Table 4 below shows the descriptive statistics estimators for the variables of interest of the research. The variables are distributed into two categories: (a) cash entropy and (b) cash synergy. Each of these categories segregates a number of quarterly observations by capital control. The estimators for effective rate $\left(\delta^{*}\right)$ and for marginal effect (MgET) must be considered in module because of the signs of PBCT and NFA that determine the direction of both variables. Thus, $\delta^{*}$ shows the effective fiscal cost per monetary unit of profit, and MgET conveys how much firms pay in excess of the nominal cost measured by $\delta$. These two variables, $\delta^{*}$ and MgET, are calculated by using the analytical models described in the Equations 6 and 7 of the previous section.

\subsubsection{Distribution with Cash Entropy}

This distribution encompasses 219 quarterly observations in the three forms of capital control. In this category, banks with governmental control present 27 quarterly observations with a mean estimator for effective tax rate, $\delta^{*}$, of $|0,1428|$ and with a marginal effect, MgET, conveying cash diseconomy of $|0,5632|$ in excess of the nominal burden, $\delta$, specifically of 0.40 and 0.45 , and asset growth equivalent to $15.08 \%$.

In the other two forms of control, private and foreign, with 70 and 122 quarterly observations each, the mean estimator for the effective rate is significantly larger than that of the governmental control, with 0.9688 and 18.9801 of the profit before DTP. Due to the difference between effective and nominal fiscal costs, MgET is enlarged to 1.38 and 18.56 in excess of the nominal fiscal burden, with asset growth of $150.3 \%$ and $71.55 \%$ respectively.

The dispersion of all the variables of interest, in this distribution category, is significant, with the smallest being greater than 4 mean standard deviations and the largest greater than 49 . This dispersion may be explained by the large range between the Min and Max limits in the three forms of capital control.

In this category, as expected, the effective rate $\left(\delta^{*}\right)$ exceeds the nominal rate $(\delta)$ because of a positive sign $(+)$ NFA that also causes MgET to be positive (+). However, if PBCT shows a negative sign (-), the MgET sign reverts to negative (-). These situations can be observed in Appendix A, Table A1.

Table 4. Descriptive statistics for the estimators of the variables of interest for the research - sample of the 40 largest banks of the finance industry in Brazil - 2010:1 to 2017:3

\begin{tabular}{|c|c|c|c|c|c|c|c|}
\hline Estimators & Mean & Median & Var.Coeff & Min & $\operatorname{Max}$ & Obs & $\Upsilon$ \\
\hline \multicolumn{8}{|c|}{ (a) Distribution with cash entropy } \\
\hline$\delta^{*}$ & $-0,1428$ & $-0,3160$ & $-49,7246$ & $-21,4217$ & 27,57374 & 27 & 1 \\
\hline $\mathrm{MgET}$ & $-0,5632$ & $-0,7660$ & $-12,613$ & $-21,8217$ & 27,17374 & 27 & 1 \\
\hline VarTA & 0,1508 & 0,0139 & 4,642097 & $-0,789$ & 2,418576 & 27 & 1 \\
\hline$\delta^{*}$ & $-0,96884$ & $-0,36749$ & $-11,0125$ & $-64,1583$ & 32,01712 & 70 & 2 \\
\hline $\mathrm{MgET}$ & $-1,38312$ & $-0,81729$ & $-7,71257$ & $-64,5583$ & 31,61712 & 70 & 2 \\
\hline VarTA & 1,503118 & 0,027926 & 5,934128 & $-0,99298$ & 66,81385 & 70 & 2 \\
\hline$\delta^{*}$ & 18,9801 & $-0,3766$ & 11,3385 & $-48,464$ & 2375,774 & 122 & 3 \\
\hline EMgT & 18,5678 & $-0,7766$ & 11,5901 & $-48,864$ & 2375,324 & 122 & 3 \\
\hline Var AtT & 0,7155 & 0,0239 & 5,4407 & $-0,9976$ & 33,8023 & 122 & 3 \\
\hline \multicolumn{8}{|c|}{ (b) Distribution with cash synergy } \\
\hline$\delta^{*}$ & $-0,3034$ & $-0,31005$ & $-0,8895$ & $-3,2907$ & 0,2928 & 252 & 1 \\
\hline MgET & $-0,7155$ & $-0,7229$ & $-0,3793$ & $-3,6907$ & $-0,1071$ & 252 & 1 \\
\hline VarTA & 0,1644 & 0,01956 & 10,2206 & $-0,9777$ & 20,6020 & 252 & 1 \\
\hline$\delta^{*}$ & $-0,3567$ & $-0,3642$ & $-1,7746$ & $-6,3030$ & 3,9265 & 333 & 2 \\
\hline MgET & $-0,7693$ & $-0,7663$ & $-0,8282$ & $-6,7530$ & 3,5265 & 333 & 2 \\
\hline VarTA & 0,0906 & 0,0250 & 13,6150 & $-0,9928$ & 22,2743 & 333 & 2 \\
\hline$\delta^{*}$ & $-0,2756$ & $-0,2720$ & $-1,9406$ & $-6,9807$ & 3,5936 & 436 & 3 \\
\hline MgET & $-0,6886$ & $-0,682$ & $-0,7769$ & $-7,3807$ & 3,1436 & 436 & 3 \\
\hline VarTA & 0,2073 & 0,0289 & 12,2630 & $-0,9940$ & 51,0241 & 436 & 3 \\
\hline
\end{tabular}

Source: the authors. $\delta^{*}=$ effective tax rate of DTP; MgET=marginal effect of direct taxation on profit; VarTA=variation in total assets.

\subsubsection{Distribution with Cash Synergy}

The concentration in this case is 1,021 quarterly observations in the three forms of capital control, which is 
equivalent to 4.66 times the number of observations in the distribution with cash entropy category. In this category, the effective rate, $\delta^{*}$, is smaller than the regular rate, $\delta$, as a result of a negative sign (-) NFA, which causes MgET also to be negative. However, if PBCT is also negative (-), then the MgET sign reverts to positive $(+)$, as demonstrated in Appendix A, Table A1.

Still in this category, differently from the previous one, the variables' mean estimators, in the three forms of capital control, show well behaved magnitudes, with an effective fiscal cost of $30.34 \%, 35,67 \%$ and $27,56 \%$ of the profit before DTP (PBCT)., for governmental, private and foreign controls, respectively. Cash economy, in this same sequence of capital control, conveyed by MgET, is $|0,7155| ;|0,7693|$; and $|0,6886|$, producing synergy.

In this category, the observations' distribution dispersion is smaller than in the previous one for the variables $\delta^{*}$ and MgET. The effect, however, is the opposite for the variable VarTA, as shown by the Var.Coef estimator. This is caused by the smaller range between the Min and Max values of the variables when compared to the previous category.

The variables behavior in the two distribution categories is in line with the findings of Boadway, Bruce, Mckenzie \& Mintz (1987), who detected a similar situation when studying the effects of profit in mining firms in Canada.

\subsection{Response to the Hypothesis Tests}

The responses shown in Table 5 below were obtained based on the linear regression theoretical model specified in the Equation (9) described in Section (4) and run by the Ordinary Least Square Method (OLS) and by Fixed Effects (FE), using the statistical package Gretl.

The results of the OLS and FE tests show that statistical significance was not found in relation to VarTA. The variable of interest NFA is statistically significant with confidence of $99 \%$. The Durbin Watson (DW), White (Lagrange Multiplier - LM) and Variance Inflation Factor (VIF) statistical tests show the absence of serial correlation, of heteroscedasticity and of collinearity, respectively, and thus suggest that the responses for the tests are robust. The soundness of the DW statistical test is confirmed because $d u \leq d \leq 4-d u$ in all tests and satisfies the condition of inexistence of positive or negative autocorrelation. The White (LM) statistical test is robust because the chi-square test $\chi^{2}(5)$ is smaller than the critical statistical values $\left(\delta_{2 \text { calc }}^{2}<\chi_{2 \text { crit }}^{2}\right)$. The VIF statistical test suggest the absence of collinearity because the regression value calculated for both is smaller than the standard score $(1.001<10)$.

With respect to the normality of residuals, the chi-square statistical test, for all tests, is smaller than the critical value, which suggests that there is no evidence that the variance is not constant. The Chow test with $F(k, n)$ is smaller than the critical statistical values and, therefore, suggests that there is no structural break.

Therefore, as shown by the results of the tests, the model has been proven to be adequately specified, and the fact that the adjusted R-squared shows low values is not relevant because the model is not predictive. These statistical tests show that MgET is statistically dependent of NFA with a lag even when the coefficient $(\beta)$ is close to zero.

Table 5. Responses to regression models run by OLS and Fixed Effects of 1,236 observations of the 40 largest banks of the finance industry in Brazil -2010:1 a 2017:3 - by asset volume - Dependent Variable: MgET

\begin{tabular}{lccc}
\hline Coefficients & OLS with intercept & OLS without intercept & FE \\
\hline Const & 2,1268 & & 2,1623 \\
VarTA-1 & 0,0242 & 0,1552 & $-0,0844$ \\
& $(0,0163)$ & $(0,1053)$ & $(-0,0569)$ \\
NFA-1 & $1,4165 \mathrm{e}-06$ & $1,3372 \mathrm{e}-06$ & $1,4503 \mathrm{e}-06$ \\
& $(3,110)^{* * *}$ & $(2,973) * * *$ & $(3,179)^{* * *}$ \\
Adjusted/centered R-squared & 0,0061 & 0,0068 & 0,0081 \\
Test F(k,n) & 4,8363 & 4,4204 & 3,73806 \\
White for heteroscedasticity: (LM) & 12,1599 & 12,0992 & 2,0006 \\
Serial correlation: Durbin-Watson $(\mathrm{k}=2)$ & 1,9981 & 1,9961 & $1,4565 \mathrm{e}+006$ \\
Normality of residuals: $\chi^{2}(2)$ & $1,4847 \mathrm{e}+006$ & $1,5072 \mathrm{e}+006$ & \\
Chow structural break: F(3, 1231/1231) & 1,8148 & 1,0943 & 1,001 \\
Collinearity: VIF-VarTA-1 & 1,001 & 1,001 & \\
Collinearity: VIF-NFA-1 & 1,001 & & \\
\hline
\end{tabular}

$\mathrm{NFA}=$ net fiscal adjustment; $\operatorname{VarTA}=$ variation in total assets. 
The results of the tests shown in this section are robust and convey that banks in Brazil consistently use the benefits of legal fiscal norms in order to reduce the burden of direct tax on profit.

However, banks must comply with two relevant indicators to be able to keep their business running, which are the Basel Index (BI) and the Fixed Asset Rate (FAR), both published in the Central Bank of Brazil statistics. Aiming at testing the degree of association of these two indicators with MgET, another regression by OLS was run considering these two indicators as independent variables. The results of the tests, which are displayed in Table 6 below, show that there is no statistical significance to the regression of BI and FAR and, beyond that, the test reveals the presence of heteroscedasticity, which shows that the variance is not constant. With these evidences, the test does not satisfy the condition of the Ordinary Least Squares method.

Table 6. Responses to regression models run by OLS - 1,236 observations of the 40 largest banks of the finance industry in Brazil -2010:1 a 2017:3 - by asset volume - Dependent Variable: MgET

\begin{tabular}{lcccc}
\hline & Coefficient & Standard Error & t-ratio & $p$-value \\
\hline const & 2,57464 & 4,93000 & 0,5222 & 0,6016 \\
BI & $-0,0900859$ & 0,203627 & $-0,4424$ & 0,6583 \\
FAR & 0,0184076 & 0,157452 & 0,1169 & 0,9070 \\
\hline R-squared & 0,000194 & Adjusted R-squared & & $-0,001423$ \\
F(2, 1237) & 0,119928 & P-value(F) & & 0,886995 \\
$\rho$ & 0,004883 & Durbin-Watson & & 1,990230 \\
\hline
\end{tabular}

\section{Conclusions}

This section presents the main results of the research that analyzed direct tax on profit in banks in Brazil and introduced the marginal effect of direct taxation (MgET). The research results bring forth robust evidences that the direct tax on profit (DTP) for banks in Brazil has a smaller effective burden than the published nominal rate. This reduction in tax burden, which the research calls cash economy/diseconomy or cash entropy/synergy, reflects efficient management of legal benefits. Positivist methodology was used to obtain the results, by means of a set of equations that define a theoretical model for data treatment. The obtained responses satisfy the research problem and planned objectives. Therefore, the results are robust and consistent with the theoretical premises of the model, as demonstrated below:

(a) the assets of the 40 banks that comprise the sample represent $83.5 \%$ of all assets in the finance industry in Brazil, which consists of more than 1,500 institutions (Central Bank of Brazil, Sept/2017). Of these 40 banks, $22.5 \%$ are controlled by the government ( $48.91 \%$ of the sample assets); in $32.5 \%$, the capital control is private (36.44\% of the sample assets); and $45 \%$ have foreign capital control (14.65\% of the sample assets).

(b) the tests report that, in general, banks manage their non-taxable revenue in such a way as to obtain the greatest benefits on their use of cash, with effective due tax rates smaller the nominal tax rates. This management is legally allowed because, normally, the amount of revenue that satisfies the condition for exclusion from the DTP calculation basis is generated by investing in related parties, where the tax is due; the research, however, has not investigated the nature of exclusions.

(c) the results reveal that the group with fewer banks, that with governmental capital control, are the ones that obtain the greatest synergy in cash economy (28 quarters of 31 in the sample), followed by private controlled banks (25.69 of 31 quarters in the sample) and, lastly, the stratification with most banks, those with foreign control, (24.30 of 31 quarters). These results reveal that the finance industry in Brazil found a structural way of economizing cash by reducing direct tax on profit.

(d) the effect of the legal norm, by using fiscal adjustments, on accounting profit to measure taxable profit is a determinant factor in the incentive/disincentive for a firm to do business in Brazil. This effect may affect shareholder fair remuneration as well as firms' working capital structure.

(e) the results allow the conclusion that NFA affects DTP in the finance industry in Brazil by reducing direct tax burden and promoting long periods of cash synergy. This conclusion is supported by the indicator MgET that conveys the reduction in tax burden when NFA $<0$ and the increase when NFA $>0$.

Finally, these results are a significant and robust contribution of the research to the enrichment of the literature with respect to the concept and measurement of the marginal effect of direct tax on profit, as well as cash synergy/entropy as a consequence of $N F A$ variation to determine tax burden because they show that the economic profit declared by firms is different from the taxable profit. However, these results are limited because they are 
restricted to the finance industry in Brazil, specifically to the banking business, and may be different if the model is applied to other sectors of the domestic economy or to the economy of other countries.

\section{References}

Boadway, R., Bruce, N., Mckenzie, K., \& Mintz, J. (1987). Marginal effective tax rates for capital in the Canadian mining industry. Canadian Journal of Economics, XX(1). https://doi.org/10.2307/135227

Brazil. (1988). Lei federal 7.689/88. Regulamento da contribuição social sobre o lucro (CSLL).

Brazil. (1999). Decreto federal $n$. 3000. Regulamento do Imposto de Renda e proventos de qualquer natureza (RIR).

Brazil. (2002). Banco Central do Brasil. Resolução 3059. Dispõe sobre registro contábil de créditos tributários das instituições financeiras e demais instituições autorizadas a funcionar pelo Banco Central do Brasil. 2002. Retrieved from http://www.bcb.gov.br/pre/normativos/res/2002/pdf/res_3059_v3_l.pdf

Brazil. (2017). Banco Central do Brasil. ifdata - Dados Selecionados de Entidades Supervisionadas. 2017. Retrieved from https://www3.bcb.gov.br/informes/relatorios

Card, D., \& Krueger, A. B. (1994). Minimum wages and employment A case study of the fast-food industry in New Jersey and Pennsylvania. The American Economic Review, 84(4).

Devereux, M. P., \& Griffith, R. (2002). The impact of corporate taxation on the location of capital: A review. Swedish Economic Policy Review, 9, 79-102.

Eberhartinger, E. (1999). The impact of rules on financial reporting in Germany, France and The UK. The International Journal of Accounting, 93-119. https://doi.org/10.1016/S0020-7063(99)80005-3

Edgeworth, F. Y. (1897). The pure theory of taxation. The Economic Journal, 7(25), 46-70. https://doi.org/10.2307/2956958

Formigoni, H., Antunes, M. T. P., \& Paulo, E. (2009). Diferença entre o lucro contábil e tributável: Uma análise sobre o gerenciamento de resultados contábeis e gerenciamento tributário nas companhias abertas brasileiras. $B B R, 6(1), 44-61$.

Graham, J. R. (1996). Debt and the marginal tax rate. Journal of Financial Economics, (41), 41-73. https://doi.org/10.1016/0304-405X(95)00857-B

Green, W. H. (2012). Econometric analysis (7th ed.). Boston: Pearson.

Holland, K., \& Jackson, R. H. G. (2004). Earnings management and deferred tax. Accounting and Business Research, 34(2), 101-123. https://doi.org/10.1080/00014788.2004.9729956

IASB-International Accounting Standard Board. (1996). Income taxes. IAS 12.

Iudícibus, S., \& Pohlmann, M. C. (2010). Relação entre a tributação do lucro e a estrutura de capital das grandes empresas no Brasil. Revista Contabilidade \& Finanças - USP, 21(53, art. 2), 1-25.

Mendoza, E. G., Razin, A., \& Tesar, L. L. (1994). Effective Tax Rates in Macroeconomics: Cross-Country Estimates of Tax Rates on Factor Incomes and Consumption. National Bureau of Economic Research. Working Paper No. 4864. https://doi.org/10.3386/w4864

Rezende, G. P., \& Nakao, S. H. (2012). Gerenciamento de resultados e a relação com o lucro tributável das empresas brasileiras de capital aberto. https://doi.org/10.4270/ruc.2012101

Ruf, M. (2012). Broadening the tax base of neutral business taxes. Economics Letters, 117, 81-83. https://doi.org/10.1016/j.econlet.2012.04.093

Schrand, C., \& Wong, M. H. F. (2003). Earnings management using the valuation allowance for deferred tax assets under SFAS 109. https://doi.org/10.1506/480D-098U-607R-5D9W

\section{Copyrights}

Copyright for this article is retained by the author(s), with first publication rights granted to the journal.

This is an open-access article distributed under the terms and conditions of the Creative Commons Attribution license (http://creativecommons.org/licenses/by/4.0/). 